Zeszyty Naukowe Szkoły Głównej Gospodarstwa Wiejskiego w Warszawie

Problemy Rolnictwa Światowego tom 18 (XXXIII), zeszyt 2, 2018: 249-258

DOI: $10.22630 /$ PRS.2018.18.2.52

Tomasz Rokicki $^{1}$, Magdalena Golonko ${ }^{2}$, Aleksandra Perkowska ${ }^{3}$

Szkoła Główna Gospodarstwa Wiejskiego w Warszawie

\title{
Zastosowanie systemów agroleśnych w krajach Unii Europejskiej
}

\section{Application of Agroforestry Systems in European Union Countries}

\begin{abstract}
Synopsis. Celem głównym badań była ocena stopnia występowania systemów agroleśnych (rolnoleśnych)w krajach Unii Europejskiej. W artykule przedstawiono koncentrację tego rodzaju upraw w krajach UE oraz określono czynniki powiązane z powierzchnia i udziałem systemów agroleśnych. Źródłem materiałów były bazy danych z EUROSTAT oraz LUCAS. Okres badań dotyczył 2015 roku Koncentracja systemów rolno-leśnych występowała w południowej Europie, a szczególnie w Hiszpanii, Portugalii, Włoszech i Grecji. W ramach danego kraju występowało duże zróżnicowanie regionalne. Największy udział systemów agroleśnych w użytkach rolnych stwierdzono na Cyprze, w Portugalii, Grecji i Bułgarii, zaś najmniejszy w Czechach, Danii i w Niemczech. Przy zastawieniu obszarów agroleśnych do terytorium kraju kolejność państw była inna. Stwierdzono bardzo silną, istotna, dodatnią zależność powierzchni systemów agroleśnych z powierzchnią kraju, powierzchnia UR oraz wartością dodaną brutto rolnictwa. Wystapienie tych prawidłowości wynika z dużego wpływu skali danego państwa i prowadzonej w nim działalności rolniczej na stosowanie systemów rolno-leśnych. Nie stwierdzono związku poziomu intensywności produkcji rolniczej ze stosowaniem systemów agroleśnych. Przyczyn stosowania systemów rolno-leśnych należy szukać w tradycji i kulturze występującej w danych krajach, a nawet regionach.
\end{abstract}

Slowa kluczowe: agroleśnictwo, systemy agroleśne, Unia Europejska

\begin{abstract}
The aim of the study was to assess the degree of use of agroforestry crops in the European Union. The article presents the concentration of this type of crops in the EU countries and identifies factors related to the area and share of agroforestry crops. The source of the materials constituted data of EUROSTAT and LUCAS. The study period concerned 2015. The concentration of agroforestry crops occurred in southern Europe, especially in Spain, Portugal, Italy and Greece. Within each given country there was a large regional diversity. The largest share of agroforestry crops in agricultural lands was found in Cyprus, Portugal, Greece and Bulgaria, while the lowest was in the Czech Republic, Denmark and Germany. The sequence was different when pledging agroforestry to the national territory. A very strong, significant, positive dependence of agroforestry crop surface area on the surface of the country, surface area of UAA and gross value added of agriculture was found. The occurrence of these regularities results from the large influence of the scale of a given country and its agricultural activity on the use of agroforestry systems. There was no relation between the intensity level of agricultural production and the use of agroforestry systems. The reasons for using agro-crops should be sought in the tradition and culture of the countries and even regions..
\end{abstract}

Key words: agroforestry, agroforestry systems, European Union

JEL Classification: Q10, Q15, Q23, Q24

\footnotetext{
${ }^{1}$ dr hab. inż., Katedra Logistyki SGGW w Warszawie, ul Nowoursynowska 166, 02-787 Warszawa, e-mail: tomasz_rokicki@sggw.pl; https://orcid.org/0000-0003-3356-2643

${ }^{2}$ mgr, Katedra Logistyki SGGW w Warszawie, ul Nowoursynowska 166, 02-787 Warszawa,

e-mail: magdalena_wiluk@sggw.pl; https://orcid.org/0000-0002-8532-6741

${ }^{3}$ mgr, Katedra Logistyki SGGW w Warszawie, ul Nowoursynowska 166, 02-787 Warszawa,

e-mail: aleksandra_perkowska@sggw.pl
} 


\section{Wprowadzenie}

Rolnictwo koncentruje się na produkcji płodów rolnych. Coraz większego znaczenia nabiera jednak ochrona środowiska, szczególnie w przypadku zagrożenia zmianami klimatycznymi. Niekorzystne zjawiska są związane ze zmianami wieloletnich trendów temperatury czy opadu oraz występowaniem ekstremalnych zjawisk pogodowych, jak. susze, fale upałów, intensywne opady, powodzie, późne przymrozki, silne wiatry. Takie zdarzenia wpływają bezpośrednio na produktywność roślin uprawnych, pastwisk i zwierząt, a także przyczyniają się do nasilenia procesów erozji gleb (SPA, 2013). Kolejnym czynnikiem mogącym prowadzić do zubożenia gleby w materię organiczną oraz składniki pokarmowe jest intensywna uprawa gruntów rolnych. Rozwiązaniem jest zrównoważone zarządzanie glebą i racjonalne wykorzystanie nawozów i środków ochrony roślin, które zmniejszają podatność upraw rolniczych na przewidywane zagrożenia klimatyczne (Borek, 2016).

Narzędziem adaptacji rolnictwa do zmian klimatu są systemy rolno-leśne, stanowiące rodzaj rolnictwa inteligentnego klimatycznie (Climate-Smart Agriculture). Z definicji system rolno-leśny, system agroleśnictwa (ang. agroforestry) jest systemem rolniczym, w którym (Somarriba, 1992):

- przynajmniej dwa gatunki roślin podlegają międzygatunkowej interakcji biologicznej,

- $\quad$ przynajmniej jeden gatunek to wieloletnia roślina drzewiasta,

- $\quad$ przynajmniej jedna z nich jest wykorzystywana na cele żywnościowe lub paszowe. Innymi słowy jest to połączenie uprawy wieloletnich roślin drzewiastych z uprawa roślin przeznaczanych na żywność lub paszę, w odpowiednim schemacie przestrzennym i następstwie czasowym (Borek, 2016).

Pierwotnie rolnictwo europejskie opierało się na zmianowaniu upraw. Oparte na drzewach systemy rolnicze pochodzą z czasów rzymskich (Lelle i Gold, 1994). Jeszcze dwa wieki temu wiele europejskich lasów było znaczącym źródłem pożywienia, a także miejscem wypasania przeżuwaczy i świń (Brownlow, 1992). W rzeczywistości nie istniała wyraźna granicy między lasem a użytkami rolnymi. W latach 70 . XX wieku nastąpiło odtwarzanie i współczesny rozwój systemów rolno-leśnych w Europie, spowodowany wzrostem zapotrzebowania na produktywność ekosystemów i na właściwe zaopatrzenie w żywność. Tym procesom towarzyszył wzrost zainteresowania sposobami gospodarowania zmniejszającymi lokalne oraz globalne zagrożenia środowiskowe, które ograniczają naturalną produktywność biosfery (Rigueiro-Rodríguez, 2009). Po raz pierwszy praktykę wykorzystania drzew w gospodarstwach rolnych terminem agroleśnictwo nazwał kanadyjski leśnik Johna Bene (Stancheva, 2007). Idea agroleśnictwa zaczęła odradzać się dzięki licznym zaletom środowiskowym takiego sposobu gospodarowania (Höchtl, 2007; Motis, 2007; Schoeneberger, 2009). Wiele współczesnych systemów agroleśnictwa jest odtworzeniem lub przetworzeniem systemów stosowanych w przeszłości (Kumar, 2016).

Z kolei Europejska Federacja Agroleśnictwa [EURAF] definiuje agroleśnictwo jako system rolniczy, w którym wieloletnie rośliny drzewiaste $\mathrm{w}$ dowolny sposób są zintegrowane z roślinami uprawnymi i/lub zwierzętami na tym samym gruncie. W licznych systemach agroleśnictwa drzewa mogą występować zarówno pojedynczo, jak i w grupach wewnątrz działek, np. w leśno-ornych systemach alejowych, charakteryzujących się pasami przemiennie drzew i upraw, systemach leśno-pastwiskowych, umożliwiających leśny 
wypas lub hodowlę zwierząt, zadrzewionych pastwiskach, sadach tradycyjnych z wypasem lub uprawą drzew owocowych, albo na granicach działek, w postaci szpalerów drzew, żywopłotów, stref buforowych, przeciwwietrznych pasów buforowych, zadrzewień przeciwerozyjnych. Najczęściej stosowane systemy agroleśnictwa w Europie według klasyfikacji A. Dzierżyńskiej przedstawiono w tabeli 1.

Tabela 1. Rodzaje systemów rolno-leśnych w Europie

Table 1. Types of agroforestry systems in Europe

\begin{tabular}{|c|c|c|}
\hline $\begin{array}{l}\text { System lub praktyka } \\
\text { agroleśnictwa }\end{array}$ & Organizacja składowych w przestrzeni & Funkcje składowych \\
\hline $\begin{array}{l}\text { Leśno-orny } \\
\text { uprawa alejowa } \\
\text { drzewa graniczne }\end{array}$ & $\begin{array}{c}\text { drzewa } \\
\text { uprawa alejowa - szeroko rozstawione rzędy lub } \\
\text { pasy przemienne drzew i upraw, } \\
\text { drzewa graniczne wokół uprawy, } \\
\text { międzyuprawa } \\
\text { roczne lub trwałe rośliny uprawne }\end{array}$ & $\begin{array}{l}\text { produkty drzewne, } \\
\text { spożywcze lub paszowe }\end{array}$ \\
\hline $\begin{array}{l}\text { Leśno-orny } \\
\text { ulepszone ugory }\end{array}$ & $\begin{array}{c}\text { drzewa szybko rosnące, najlepiej z symbiozą } \\
\text { azotową } \\
\text { pole odłogowane }\end{array}$ & $\begin{array}{c}\text { poprawa żyzności gleby, } \\
\text { produkty drzewne (biopaliwo) }\end{array}$ \\
\hline $\begin{array}{l}\text { Leśno-orny i leśno- } \\
\text { pastwiskowy } \\
\text { Drzewa } \\
\text { wielofunkcyjne }\end{array}$ & $\begin{array}{l}\text { drzewa owocowe lub inne, przypadkowo lub } \\
\text { systematycznie rozmieszczone, rzadko } \\
\text { rozproszone - krajobraz parkowy, } \\
\text { pole uprawne lub pastwisko }\end{array}$ & $\begin{array}{l}\text { produkcja owoców, drewna, } \\
\text { opału, upraw i paszy }\end{array}$ \\
\hline Leśno-pastwiskowy & $\begin{array}{c}\text { drzewa lasu naturalnego - rozmieszczenie } \\
\text { przypadkowe, lub sztucznego - rozmieszczenie } \\
\text { systematyczne } \\
\text { uprawa i wypas pod koronami drzew uprawaroślin } \\
\text { paszowychjednorocznych i trwałych wypas } \\
\text { zwierząt gospodarskich }\end{array}$ & $\begin{array}{l}\text { produkty drzewne, ochrona } \\
\text { iłona dla zwierząt, produkty } \\
\text { zwierzęce }\end{array}$ \\
\hline Gospodarstwo leśne & $\begin{array}{c}\text { drzewa lasu naturalnego - rozmieszczenie } \\
\text { przypadkowe lub sztucznego - rozmieszczenie } \\
\text { systematyczne } \\
\text { uprawa pod koronami drzew } \\
\text { rośliny specjalne, cieniolubne, grzyby }\end{array}$ & $\begin{array}{l}\text { produkty drzewne, spożywczo- } \\
\text { przyprawowe, medyczne lub } \\
\text { dekoracyjne }\end{array}$ \\
\hline $\begin{array}{l}\text { Nadbrzeżne pasy } \\
\text { buforowe }\end{array}$ & $\begin{array}{c}\text { pasy roślinności trwałej-drzewa/krzewy/ trawy } \\
\text { naturalne lub sztuczne pomiędzy polem i zasobami } \\
\text { wodnymi - strumień, staw, jezioro, mokradło }\end{array}$ & $\begin{array}{l}\text { ochrona jakości wody, } \\
\text { bioróżnorodność }\end{array}$ \\
\hline
\end{tabular}

Źródło: opracowanie własne na podstawie Dzierżyńska A. (2011). Agroleśnictwo - zacofanie czy postęp? Postępy Nauk Rolniczych 4, 129-141.

Agroleśnictwo można także zdefiniować jako dynamiczny, oparty na zasadach ekologicznych system zarządzania zasobami naturalnymi, który poprzez integrację drzew w gospodarstwach rolnych i krajobrazie rolniczym dywersyfikuje i podtrzymuje produkcję, zwiększając korzyści społeczne, gospodarcze i środowiskowe dla użytkowników gruntów na wszystkich poziomach. W szczególności agroleśnictwo ma zasadnicze znaczenie dla drobnych rolników i innych mieszkańców obszarów wiejskich. Wielostronne systemy mogą zapewnić szeroki zakres korzyści ekonomicznych, społeczno-kulturowych i środowiskowych (FAO, 2015). 
W Europie istnieje wiele systemów agroleśnych, jednak największy obszarowo z nich bazujący na tradycyjnej technologii agroleśnictwa, znajduje się w rejonie śródziemnomorskim na terenie Hiszpanii (Dehesa) i Portugalii (systemy Montado and Mosaic) (Pachana, 2017). Systemy te są stworzonymi przez człowieka ekosystemami charakteryzującymi się strukturą przypominającą sawannę i bardzo wysoką różnorodnością biologiczną, gdzie drzewa (głównie dąb ostrolistny, Quercus ilex) są postrzegane jako integralna część systemu. Dlatego też drzewa są sadzone, zarządzane i regularnie przycinane. Są tradycyjnie wypasane przez różne zwierzęta hodowlane i są prawdopodobnie najstarszymi agroleśnymi systemami, które wciąż istnieją w Europie. Tego typu obszary powstały około dwa tysiące lat temu i niewiele zmieniły się aż do ostatnich 30-40 lat (Jacobson, 2014). Innymi systemami agroleśnictwa w Europie w rejonie strefy umiarkowanej są: systemy z ogławianymi drzewami w Europie Północnej, Alpach i Pirenejach, szwajcarskie pastwiska leśne w górach Jura, brytyjskie i bałkańskie lasy z hodowlą dzika i świń. Do systemów leśno-pastwiskowych zalicza się sady tradycyjne z wypasem w takich krajach, jak Wielka Brytania, Francja, Holandia, Hiszpania (RigueiroRodríguez, 2009; Wojtkowski, 2006).

Istotną kwestią w utrzymaniu i wprowadzaniu nowych systemów rolno-leśnych jest wymiana i transfer wiedzy pomiędzy środowiskiem naukowym a praktykami w dziedzinie agroleśnictwa. Wspólna Polityka Rolna Unii Europejskiej wspiera wielofunkcyjny rozwój obszarów wiejskich, promuje integrowany oraz ekologiczny system gospodarowania oraz zrównoważoną produkcję energii z odnawialnych źródeł, co jest szczególnie istotne w związku ze zmianami klimatu (Borek, 2016). Wyzwaniami, jakie stoją przed upowszechnieniem agroleśnictwa w Europie, są m.in. pokonanie barier prawnych, nie tylko na poziomie krajowym, ale też w ramach polityki dostosowywania do Europejskiego systemu biurokracji, brak wsparcia legislacyjnego oferowanego rolnikom oraz dyskryminowanie systemów rolno-leśnych, m.in. ze względu na istniejące ograniczenia w łączeniu systemów rolnego i leśnego, blokowaniu rozwoju produkcji w pewnych kierunkach, np. produkcji zwierzęcej, czy limit liczby drzew na hektarze (AFINET, 2017).

Reasumując, obecnie w rolnictwie powinno przejść od „totalitaryzmu” w postaci monokultur do „demokracji” w formie polikultur, reprezentowanych przez praktyki i systemy agroleśnictwa (Dzierżyńska, 2011).

\section{Materiał i metodyka badań}

Celem głównym badań była ocena stopnia występowania systemów agroleśnych w krajach Unii Europejskiej. Celami szczegółowymi było przedstawienie stopnia koncentracji systemów rolno-leśnych w UE, wskazanie znaczenia tego typu produkcji w poszczególnych krajach UE oraz określenie czynników powiązanych z powierzchnia i udziałem systemów agroleśnych w UR i powierzchni kraju. Źródła materiałów stanowią dane publikowane $\mathrm{w}$ bazach danych EUROSTAT oraz LUCAS (uzyskane na podstawie danych teledetekcyjnych). Okres badawczy obejmował 2015 rok. Dane dotyczą wszystkich krajów UE. W pracy wykorzystano metodę porównawczą, obliczono współczynnik koncentracji Giniego oraz przedstawiono stopień koncentracji za pomocą krzywej Lorenza. Do określenia związków między systemami agroleśnymi a innymi parametrami zastosowano współczynnik korelacji liniowej Pearsona. Do prezentacji wyników badań zastosowano formę opisową, tabelaryczna i graficzną. 


\section{Wyniki badań}

Według autorów analizujących rozkład występowania systemów rolno-leśnych całkowity obszar systemów określanych jako agroleśnictwo w UE wynosił około 24 milionów ha, co odpowiadało około 5,7\% powierzchni terytorialnej oraz 14\% użytków rolnych. Powierzchnia i udział systemów agroleśnych w poszczególnych krajach były zróżnicowane. W pierwszej kolejności zbadano nierównomierność rozkładu systemów rolno-leśnych. Do określenia stopnia koncentracji upraw agroleśnych w krajach Unii Europejskiej zastosowano współczynnik Giniego. Dane dotyczyły roku 2015, zaś liczba obserwacji wynosiła 28. Współczynnik Giniego obliczony z próby wyniósł 0,66, zaś estymowany współczynnik dla populacji 0,68. Oznacza to bardzo dużą koncentrację upraw agroleśnych w kilku krajach UE. Dodatkowo te zróżnicowanie przedstawia krzywa koncentracji Lorenza (rys. 1). Najwięcej hektarów upraw agroleśnych było w Hiszpanii, bo aż 28\% tych użytków dla całej UE. Na kolejnych miejscach znajdowały się Francja (11\%), Włochy i Grecja (po 9\%) oraz Rumunia i Portugalia (po 8\%). Systemy agroleśne były więc zlokalizowane na południu Europy. W krajach z top 6 było $73 \%$ całkowitej powierzchni tych upraw. Systemy rolno-leśne były mało popularne w krajach o intensywnym rolnictwie, $\mathrm{z}$ przewagą upraw w monokulturze.

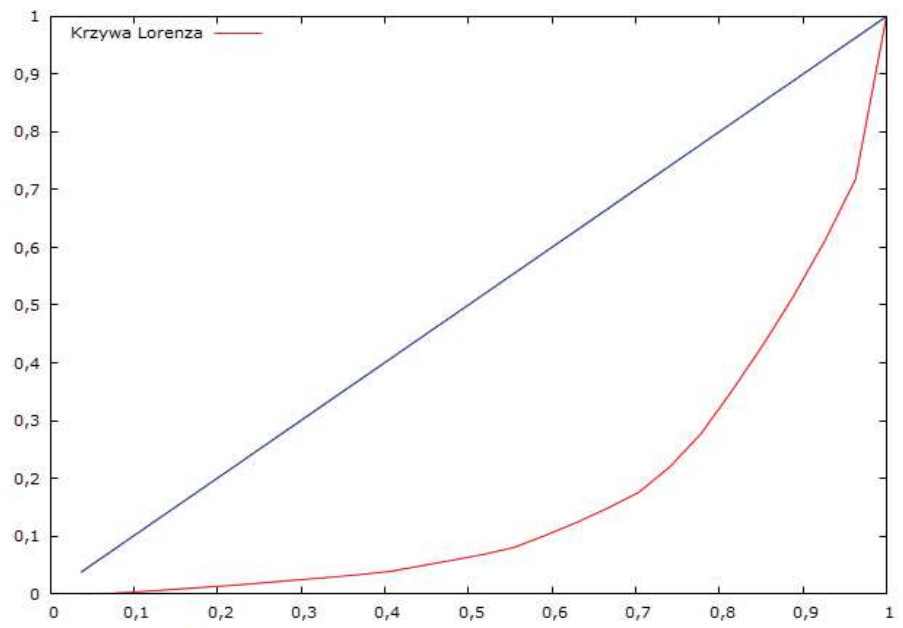

Rys. 1. Krzywa koncentracji Lorenza dla powierzchni systemów agroleśnych w krajach UE w 2015 roku

Fig. 1. Lorenz concentration curve for the agroforestry area in EU countries in 2015

Źródło: opracowanie własne na podstawie danych EUROSTAT, LUCAS.

Poszczególne systemy agroleśnictwa przenikają się, co oznacza, że na danym obszarze są często dwa rodzaje, jak np. agroleśnictwo na terenach ważnych przyrodniczo i kulturowo oraz z wykorzystaniem zwierząt. Około $80 \%$ systemów agroleśnych jest prowadzona na terenach o wysokiej wartości przyrodniczej i kulturowej, zaś agroleśnictwo z wykorzystaniem zwierząt gospodarskich dotyczy 40\% wszystkich systemów rolnoleśnych. Udział pozostałych systemów był znikomy.

Pierwszą ocenę systemów agroleśnych z uwzględnieniem poszczególnych krajów i regionów UE przeprowadzili Plieninger z zespołem (2015). Przedmiotem badań były 
pastwiska leśne. W opracowaniu autorzy zwrócili uwagę na wielofunkcyjny charakter pastwisk leśnych. Z kolei Herder i jego zespół (2016, 2017) dokonali określenia liczbowego i za pomocą map rozmieszczenia systemów agroleśnych w Unii Europejskiej. Przy zastosowaniu danych o użytkowaniu gruntów i pokryciu terenu LUCAS określono powierzchnię systemów rolno-leśnych oraz ich udział w powierzchni krajów.

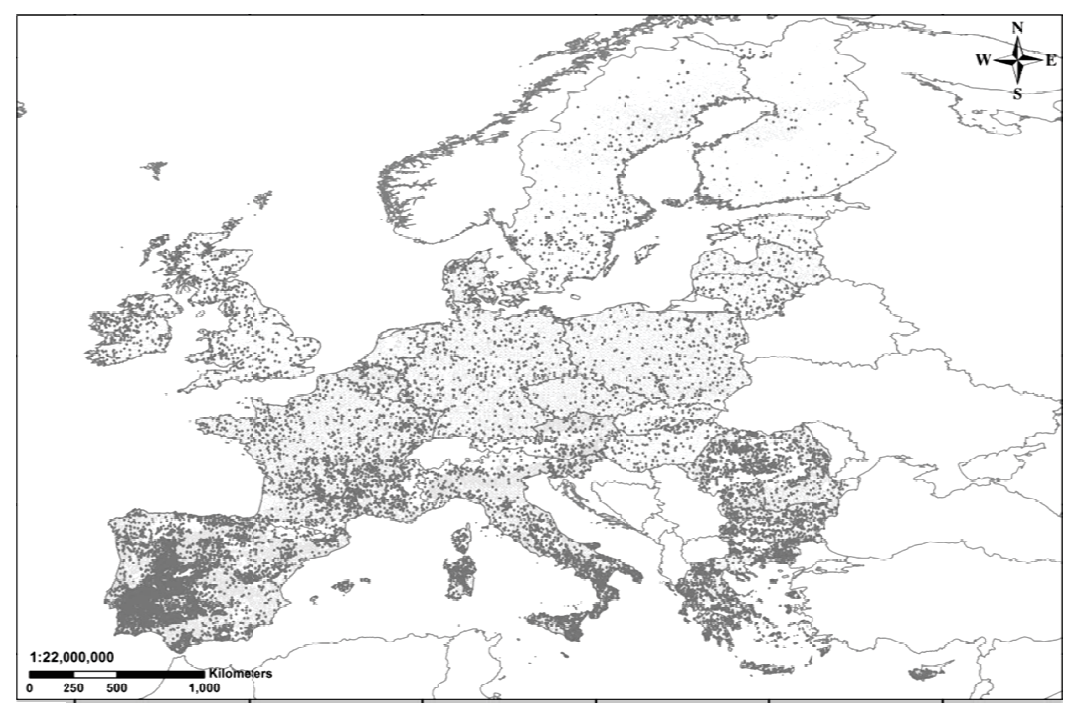

Rys. 2. Położenie systemów agroleśnych w Unii Europejskiej w 2015 roku

Fig. 2. Location of agroforestry systems in the European Union in 2015

Źródło: M. den Herder et al. (2016). Current extent of agroforestry in Europe, 3rd European Agroforestry Conference, Montpellier, 23-25 May 2016.

Odnosząc się bardziej szczegółowo do miejsc stosowania systemów agroleśnych można zobrazować ich przestrzenną koncentrację (rys. 2). Dużą powierzchnię obszarów podlegających agroleśnictwu można znaleźć w południowej, środkowej i północnowschodniej Portugalii, południowo-zachodniej, środkowej i części północnej Hiszpanii, południowej Francji, w Sardynii, na Sycylii i południowych Włoszech, w centralnej i północnej części kraju. północno-wschodniej Grecji, środkowej i zachodniej Bułgarii, środkowej i północnej Rumunii oraz w zachodnim Cypr. Systemy agroleśne były powiązane najczęściej z ekstensywnym rolnictwem. Przykładem jest wypas zwierząt w obszarach trudno dostępnych lub niedostępnych dla maszyn. Największy udział systemów z wykorzystaniem zwierząt w systemów rolno-leśnych odnotowano na Cyprze $(71 \%)$, w Holandii (69\%) i w Finlandii (66\%). We wszystkich krajach UE udział systemów z wykorzystaniem zwierząt stanowił co najmniej 10\% systemów agroleśnych.

W poszczególnych krajach UE znaczenie upraw agroleśnych w rolnictwie było zróżnicowane (rys. 3). Na Cyprze stanowiły one aż 77\% użytków rolniczych, w Portugali 50\%, w Grecji 40\% a w Hiszpanii i Bułgarii około 30\%. Były też Państwa z marginalnym znaczeniem systemów agroleśnych w użytkach rolniczych, jak Czechy, Dania, Niemcy i Polska (3-4\%). Występowanie systemów agroleśnych można więc powiązać przede 
wszystkim z intensywnością i specyfiką rolnictwa w danym kraju. Mniejsze znaczenie miało występowanie obszarów, które można zaadaptować na rzecz agroleśnictwa.

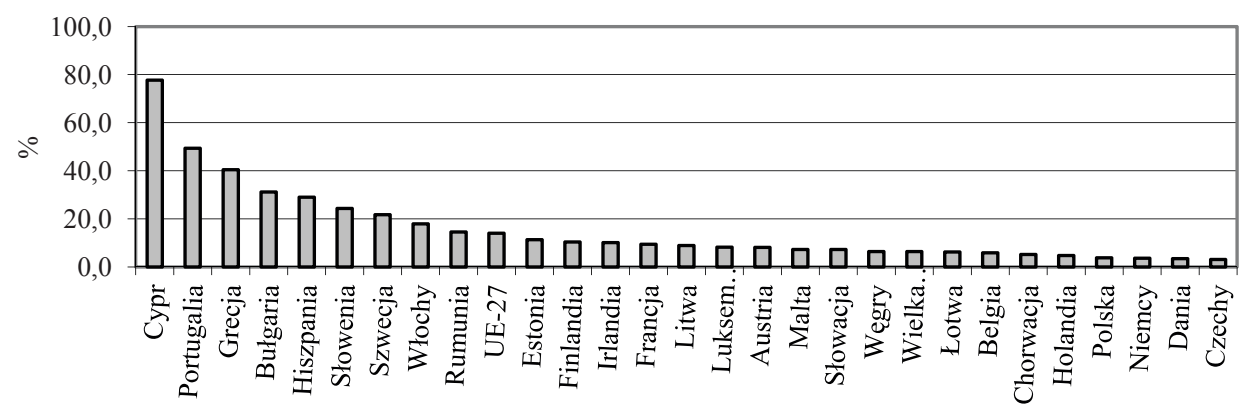

Rys. 3. Udział powierzchni systemów agroleśnych w użytkach rolniczych w krajach UE w 2015 roku (\%)

Fig. 3. Share of agroforestry area in utilised agricultural area in EU countries in 2015 (\%)

Źródło: jak na rys. 1.

Biorąc pod uwagę udział upraw agroleśnych w powierzchni terytorium kraju wyniki są inne niż przy udziale w użytkach rolnych (rys. 4). Na Cyprze uprawy agroleśne stanowiły tylko $10 \%$ powierzchni kraju, zaś w Portugalii aż 20\%, Grecji 16\%, Bułgarii i Hiszpanii po 13\%. Duży udział upraw agroleśnych w powierzchni kraju był też w Rumunii (8\%), mimo że udział w użytkach rolnych stanowił tylko 15\%. Szczegółowe badania w dalszej części artykułu pozwolą stwierdzić występowanie lub brak prawidłowości w tym zakresie.

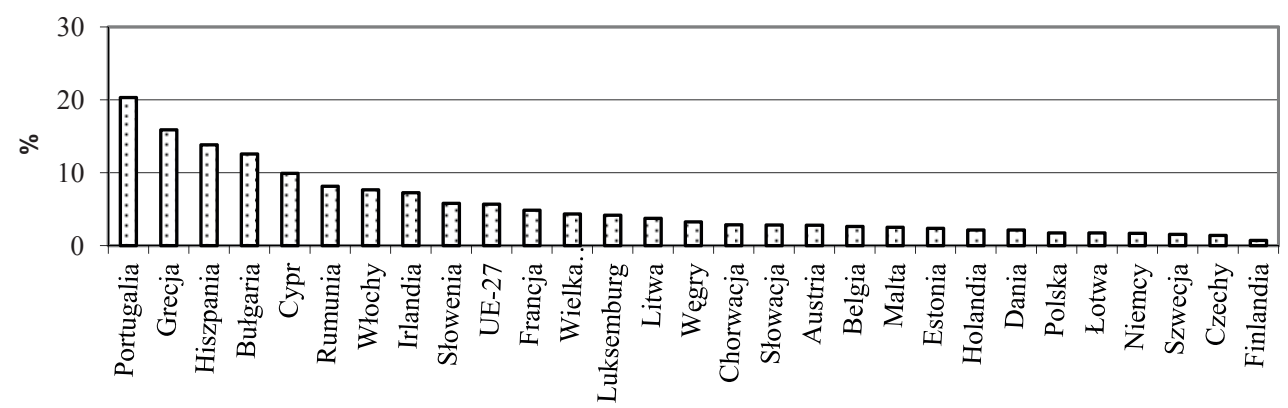

Rys. 4. Udział systemów agroleśnych w powierzchni terytorium w krajach UE w 2015 roku (\%)

Fig. 4. Share of agroforestry area in the territorial area in EU countries in 2015 (\%)

Źródło: jak na rys. 1.

W celu stwierdzenia związku między uprawami agroleśnymi w krajach Unii Europejskiej a parametrami, które mogły na nie wpływać zostały obliczone współczynniki korelacji liniowej Pearsona (tab. 1). Jako wartość graniczną poziomu istotności przyjęto $\mathrm{p}=0,05$. Istotne wyniki zostały oznaczone szarym tłem $\mathrm{w}$ tabeli. Współczynniki korelacji zostały policzone dla krajów UE w 2015 roku. W pracy starano się sprawdzić korelację, która nie wskazuje że dany czynnik wpływa na inny, tylko że istnieje między nimi silny lub słaby związek. Stwierdzono silne dodatnie związki powierzchni upraw agroleśnych z 
powierzchnią kraju $(\mathrm{r}=0,645$, $\mathrm{p}$-value $=0,001), \mathrm{UR}(\mathrm{r}=0,721, \mathrm{p}$-value $=0,001)$ oraz o mniejszej sile $\mathrm{z}$ areałem lasów w kraju $(\mathrm{r}=0,367$, $\mathrm{p}$-value $=0,050)$. Takie zależności są dosyć logiczne. Im większa była powierzchnia kraju, tym więcej było upraw agroleśnych. Określone w artykule obszary koncentracji systemów agroleśnych występowały w największych krajach UE, położonych na południu kontynentu. Silne dodatnie zależności stwierdzono również $\mathrm{w}$ relacji między powierzchnią upraw agroleśnych a wartością dodaną brutto rolnictwa $(\mathrm{r}=0,690, \mathrm{p}$-value $=0,001)$. Tutaj również znaczenie miała skala produkcji. Przy uwzględnieniu produktywności jednostkowej rolnictwa (wartość dodana brutto rolnictwa przeliczonej na 1 hektar UR) nie zaobserwowano związku z powierzchnią upraw agroleśnych. Oznacza to, że występowanie systemów agroleśnych nie było uzależnione od poziomu intensywności produkcji rolniczej. Dokonano również analizy relacji między udziałem upraw agroleśnych w UR a wybranymi parametrami oraz analogicznie dla udziału upraw agroleśnych w powierzchni terytorium kraju. Zależności były nieistotne, co potwierdza tezę, że udział upraw agroleśnych był niezależny od powierzchni i struktury użytkowanych gruntów oraz od intensywności i wartości produkcji rolniczej.

Tabela 1. Współczynniki korelacji między systemami agroleśnymi i wybranymi parametrami

Table 1 . The correlation coefficients between agroforestry systems and selected parameters

\begin{tabular}{l|cc}
\hline \multicolumn{1}{c}{ Parametry } & $\begin{array}{c}\text { Współczynniki korelacji liniowej Pearsona } \\
\text { korelacja }\end{array}$ & p-value \\
\hline Współczynniki korelacji między powierzchnią systemów agroleślnych a & & 0,001 \\
powierzchnią kraju & 0,645 & 0,001 \\
powierzchnią UR & 0,721 & 0,050 \\
powierzchnią lasów & 0,367 & 0,001 \\
wartością dodaną brutto rolnictwa & 0,690 & 0,715 \\
wartością dodaną brutto rolnictwa na 1 ha UR & $-0,072$ & 0,833 \\
Współczynniki korelacji między udziałem systemów agroleślnych w powierzchni UR a & 0,669 \\
powierzchnią kraju & $-0,042$ & 0,937 \\
powierzchnią UR & $-0,084$ & 0,076 \\
powierzchnią lasów & $-0,016$ & 0,955 \\
udziałem UR w powierzchni całkowitej & $-0,341$ & 0,859 \\
udziałem gruntów leśnych w powierzchni całkowitej & 0,011 & 0,825 \\
wartością dodaną brutto rolnictwa & $-0,035$ & 0,044 \\
wartością dodaną brutto rolnictwa na 1 ha UR & 0,052 & 0,791 \\
Współczynniki korelacji między udziałem systemów agroleślnych w powierzchni całkowitej kraju a \\
powierzchnią kraju & 0,052 \\
powierzchnią UR & 0,176 & 0,371 \\
powierzchnią lasów & $-0,098$ & 0,621 \\
udziałem UR w powierzchni całkowitej & 0,128 & 0,515 \\
udziałem gruntów leśnych w powierzchni całkowitej & $-0,166$ & 0,399 \\
wartością dodaną brutto rolnictwa & 0,181 & 0,357 \\
wartością dodaną brutto rolnictwa na 1 ha UR & $-0,061$ & 0,757 \\
\hline
\end{tabular}

Źródło: jak na rys. 1.

Przedstawione zależności potwierdzają niezależność stosowania systemów agroleśnych od struktury użytkowanych gruntów oraz intensywności produkcji rolniczej. Przyczyn stosowania systemów rolno-leśnych należy szukać $\mathrm{w}$ tradycji i kulturze występującej w danych krajach, a nawet regionach. Poziom regionalny rozważań pozwoli 
stwierdzić właściwe czynniki powiązane ze stosowaniem systemów agroleśnych. Takie rozważania będą kontynuacją i rozwinięciem badań zaprezentowanych w artykule.

\section{Podsumowanie}

W artykule przedstawiono sytuację $\mathrm{w}$ zakresie systemów agroleśnych w krajach UE. Stwierdzono bardzo dużą koncentrację i występowanie dużego zróżnicowania tych upraw, o czym świadczy obliczony współczynniki Giniego oraz krzywa koncentracji Lorenza. Systemy agroleśne skoncentrowane były w kilku państwach UE położonych na południu Europy, a największy ich areał był w Hiszpanii. Jednocześnie w ramach krajów występowało duże zróżnicowanie, bo uprawy koncentrowały się w kilku regionach.

Kolejnym wyznacznikiem znaczeniu systemów rolno-leśnych w poszczególnych krajach UE był udział tych obszarów w powierzchni UR i terytorium kraju. W przypadku odniesienia do powierzchni UR największy udział systemów agroleśnych stwierdzono na Cyprze (aż 77\%), Portugali (50\%) oraz w Grecji $(40 \%)$. W tych krajach produkcja rolnicza była bardzo powiązana ze stosowaniem zadrzewień, czy pojedynczych drzew. Na drugim biegunie były państwa o bardzo małym znaczeniu systemów agroleśnych w UR, jak Czechy, Dania i Niemcy (3-4\%). W przypadku udziału systemów rolno-leśnych w powierzchni terytorium kraju kolejności była inna. W Portugali 20\% powierzchni kraju podlegała systemom agroleśnym, a na Cyprze tylko 10\%. Duże znaczenie tym przypadku miało występowanie jezior, rzek i innych gruntów nieużytkowanych rolniczo, a także struktura gruntów.

Ostatnia część analizy polegała na ustaleniu związku między systemami agroleśnymi w krajach UE a wybranymi parametrami mogącymi wpływać na nie. Stwierdzono bardzo silna, istotna, dodatnią zależność powierzchni systemów rolno-leśnych $\mathrm{z}$ badanymi parametrami w przypadku powierzchni kraju, powierzchni UR oraz wartości dodanej brutto rolnictwa. Wystapienie tych prawidłowości wynika z dużego wpływu skali danego państwa i prowadzonej w nim działalności rolniczej na stosowanie systemów agroleśnych. Jednocześnie udział systemów rolno-leśnych w użytkach rolnych, jak i w powierzchni kraju nie były skorelowane $\mathrm{z}$ żadnym $\mathrm{z}$ parametrów. Nie stwierdzono związku poziomu intensywności produkcji rolniczej ze stosowaniem systemów agroleśnych. Przyczyn stosowania systemów rolno-leśnych należy szukać w tradycji i kulturze występującej w danych krajach, a nawet regionach.

\section{Literatura}

AFINET (AgroForestry Innovation NETworks) (2017). Pobrano z: http://www.zpkww.pl/zalaczniki/AFINET_ pressrelease_1st_campaign_PL.pdf.

Borek, R. (2016). Znaczenie systemów rolno-leśnych i możliwości wsparcia ich rozwoju w ramach Wspólnej Polityki Rolnej UE (The role of agroforestry systems and opportunities for their support within the framework of the Common Agricultural Policy in EU). Zagadnienia Doradztwa Rolniczego, 1(83), 22-38.

Brownlow, M.J.C. (1992). Acorns and swine: Historical lessons for modern agroforestry. Quarterly Journal of Forestry, 86, 181-190. 
den Herder, M., Moreno, G., Mosquera-Losada, R., Palma, J., Sidiropoulou, A., Santiago Freijanes, J., CrousDuran, J., Paulo, J., Tomé, M., Pantera, A., Papanastasis, V., Mantzanas, K., Pachana, P., Plieninger, T., Burgess, P. (2016). Current extentof agroforestery in Europe, 3rd European Agroforestry Conference, Montpellier, 23-25 May 2016.

den Herder, M., Moreno, G., Mosquera-Losada, R., Palma, J., Sidiropoulou, A., Santiago Freijanes, J., CrousDuran, J., Paulo, J., Tomé, M., Pantera, A., Papanastasis, V., Mantzanas, K., Pachana, P., Plieninger, T., Burgess, P. (2017). Current extent and stratification of agroforestry in the European Union. Agriculture, Ecosystems \& Environment, 241, 121-132.

Dzierżyńska, A. (2011). Agroleśnictwo w Europie - zacofanie czy postęp? (Agroforestry in Europe underdevelopment or progress?). Postępy Nauk Rolniczych, 63(4), 129-141.

EURAF (European Agroforestry Federation). Pobrano z: http://www.agroforestry.eu.

FAO (2015). Pobrano z: http://www.fao.org/forestry/agroforestry/80338/en/.

Höchtl, F., Rusdea, E., Schaich, H., Wattendorf, P., Bieling, C., Reeg, T., Konold, W. (2007). Building bridges, crossing borders: Integrative approaches to rural landscape management in Europe. Norsk Geografisk Tidsskrift - Norwegian Journal of Geography, 61(4), 157-169.

Jacobson, M. (2014). Dehesa Agroforestry Systems. Association for Temperate Agroforestry, No. 4.

Kumar, B.M. (2006). Agroforestry: the new old paradigm for Asian food security - Review/synthesis. Journal of Tropical Agriculture, 44(1-2), 1-14.

Lelle, M.A., Gold, M.A. (1994). Agroforestry systems for temperate climates: Lessons from Roman Italy. Forest \& Conservation History, 38, 118-126.

Motis, T. (2007). Agroforestry principles. Echo. Pobrano z: http://www.echonet.org.

Pachana, P. (2017). Agroleśnictwo w Europie (Agroforestry in Europe). Monitor Leśny. Pobrano z: http://www.forest-monitor.com/pl/agrolesnictwo-w-europie/.

Plieninger, T., Hartel, T., Martín-Lópeza, B., Beaufoy, G., Bergmeier, E., Kirby, K., Montero, M.J., Moreno, G., Oteros-Rozas, E., Van Uytvanck, J., (2015). Wood-pastures of Europe: Geographic coverage, socialecological values, conservation management, and policy implications. Biological Conservation, 190, 70-79.

Rigueiro-Rodríguez, A., McAdam, J., Mosquera-Losada, M.R. (red.) (2009). Agroforestry in Europe - current status and future prospects. Springer: 452.

Schoeneberger, M.M. (2009). Agroforestry: working trees for sequestering carbon on agricultural lands. Agroforestry Systems, 75, 27-37.

Somarriba, E. (1992). Revisiting the past: an essay on agroforestry definition. Agroforestry Systems, 19, 233-240.

SPA. Strategiczny plan adaptacji dla sektorów i obszarów wrażliwych na zmiany klimatu do roku 2020 z perspektywą do roku 2030 (Strategic adaptation plan for sectors and areas sensitive to climate change by 2020). (2013). https://klimada.mos.gov.pl/wp-content/uploads/2013/11/SPA-2020.pdf

Stancheva, J., Bencheva, S., Petkova, K., Piralkov, V. (2007). Possibilities for agroforestry development in Bulgaria: Outlooks and limitations. Ecological Engineering, 29, 382-387.

Wojtkowski, P.A. (2006). Introduction to agroecology - principles and practices. Food Products Press.

Do cytowania / For citation:

Rokicki T., Golonko M., Perkowska A. (2018). Zastosowanie systemów agroleśnych w krajach Unii Europejskiej. Problemy Rolnictwa Światowego, 18(2), 249-258; DOI: 10.22630/PRS.2018.18.2.52

Rokicki T., Golonko M., Perkowska A. (2018). Application of Agroforestry Systems in European Union Countries (in Polish). Problems of World Agriculture, 18(2), 249-258;

DOI: $10.22630 /$ PRS.2018.18.2.52 